\title{
Physical Attributes of the Soil and Maize Productivity Under an Intercrop System
}

\author{
Paulo Ricardo Alves dos Santos ${ }^{1}$, Carlos Alessandro Chioderoli ${ }^{2}$, Alexsandro Oliveira da Silva ${ }^{1}$, \\ Francisca Edcarla de Araújo Nicolau ${ }^{3}$, José Evanaldo Lima Lopes ${ }^{1}$, \\ Marcelo Queiroz Amorim ${ }^{1} \&$ Clice de Araújo Mendonça ${ }^{1}$ \\ ${ }^{1}$ Department of Agricultural Engineering, Federal University of Ceará, Brazil \\ ${ }^{2}$ Federal University of Triângulo Mineiro, Brazil \\ ${ }^{3}$ State University of São Paulo Júlio de Mesquita Filho, Brazil \\ Correspondence: Paulo Ricardo Alves dos Santos, Department of Agricultural Engineering, Federal University \\ of Ceará, Brazil. E-mail: paulo_ptg@yhaoo.com.br
}

Received: August 13, 2018

doi:10.5539/jas.v10n12p358
Accepted: September 22, $2018 \quad$ Online Published: November 15, 2018

URL: https://doi.org/10.5539/jas.v10n12p358

\begin{abstract}
The intensive use of agricultural areas for farming, together with inadequate management, can cause soil degradation and promote a low-quality environment for crops; An intercrop system of maize and forage can therefore be an alternative to existing production systems. The aim of this study was to identify the effect of intercropping maize with forage on the physical attributes of the soil and on productivity in maize, as a function of the sowing season and different forages, in the northeastern region of Brazil. A trial intercrop of maize with three forages (Brachiaria brizantha, Panicum maximum 'Mombasa', and Crotalaria spectabilis a.) was planted at two different times: phase 1-forage sown between the rows of maize, mixed with the basal dressing; and phase 2-forage sown between the rows, at the V4 stage in maize; in addition to maize with no intercrop (control). The trial was carried out in a randomised block design, with four replications. Forage Mombasa inserted in phase 1 (1) and phase (2) of sowing favored higher values of macroporosity in the layers $0.0-0.10 \mathrm{~m}$ and $0.10-0.20 \mathrm{~m}$ respectively. For the mass of 1000 grains and grain yield, there were no significant differences between the treatments when compared to the exclusive corn. It was concluded that the maize-forage intercrop promotes changes in the physical attributes of the soil (macroporosity, total porosity and density), and that maize productivity is not affected by the intercrop system.
\end{abstract}

Keywords: sowing times, soil physics, sustainable systems, Zea mays

\section{Introduction}

Maize (Zea mays L.) is the second most cultivated cereal in the world (Simão, 2016). In addition to being an annual crop that most stands out when intercropped with forages, it has an economic importance characterised by its many forms of use.

The use of conservation systems is becoming increasingly more frequent in the different regions of Brazil, as these systems offer advantages to the environment, as well as greater crop productivity (Coser et al., 2016; Carvalho et al., 2015). Among conservation activities, intercropping is important and a well-known agricultural practice in all tropical regions.

Intercropping consists of the simultaneous cultivation of two or more crops in the same area, not necessarily planted or sown at the same time (Magalhães et al., 2013).

Forage plants, when intercropped with maize, can be sown either together with the maize crop, or about 10 to 20 days after maize has emerged. Neto et al. (2012) report that sowing time is one variable that can directly interfere with the development and yield of the main crop, and it is necessary for producers to have knowledge of the best time of sowing to avoid being unsuccessful. In literature, a number of authors have reported that the presence of forage does not affect grain yield of maize (Ferreira et al., 2017; Garcia et al., 2013).

Management practices cause changes in the physical properties of the soil, affecting the development of the plants and, consequently, the productivity (Lobato et al., 2018). Arcoverde et al., (2015) evaluating indicators of 
the physical quality of the soil, concluded that the attributes of bulk density, macroporosity and microporosity were the best indicators of soil quality.

One of the measures recommended for improving the physical quality of the soil is the adoption of systems that include plants with abundant, deep and aggressive root systems. Mendonça et al. (2013), and Flavio Neto et al. (2015) reported that the root systems of forage plants can positively affect the physical properties of the soil, favouring infiltration of water and improving aeration, thereby allowing better development of the root system with better use of the soil profile. This results in greater absorption of water and nutrients, which can culminate in an increase in crop production.

In the northeast of Brazil, increases in agricultural production are linked to the opening up of new areas and not to increased productivity by the adoption of appropriate technologies and management. Therefore, due to the lack of information regarding forage types and sowing time suitable for a maize-forage intercrop system in the northeast of Brazil, the present study originated from the following hypothesis: that the inclusion of forage plants in a system of grain cultivation alters the physical properties of the soil, and reduces the productivity of maize.

The aim of the present study was to identify variations in the physical attributes of the soil and in maize productivity due to sowing time and different intercrop configurations, under a maize-forage intercrop system in the northeast of Brazil.

\section{Material and Methods}

\subsection{Description of the Experimental Site}

The experiment was conducted at a site in the city of Fortaleza in the State of Ceará, Brazil, at $03^{\circ} 43^{\prime} \mathrm{S}$ and $38^{\circ} 32^{\prime} \mathrm{W}$, at an altitude of $19 \mathrm{~m}$. The soil used was classified as a Red Yellow Argisol, as per Embrapa methodology (2013), comprising $83 \%$ sand, $10.60 \%$ clay and $6.40 \%$ silt.

According to the Koppen classification, the climate in the region is type Aw, tropical rainy with precipitation in the summer-autumn and annual average temperatures of $28^{\circ} \mathrm{C}$ and precipitation of $900 \mathrm{~mm}$.

Initial soil samples were collected for physcal and chemical characterisation of the $0.0-0.10 ; 0.10-0.20$ e and 0.20-0.30 layer before setting up the experiment (Tables 1 and 2).

Table 1. Physcal characteristics of the soil in the experimental site

\begin{tabular}{llll}
\hline Depth $(\mathrm{m})$ & Macroporosity $\left(\mathrm{m}^{3} \mathrm{~m}^{-3}\right)$ & Microporosity $\left(\mathrm{m}^{3} \mathrm{~m}^{-3}\right)$ & Total porosity $\left(\mathrm{m}^{3} \mathrm{~m}^{-3}\right)$ \\
\hline $0.0-0.10$ & 0.09 & 0.14 & 0.23 \\
$0.10-0.20$ & 0.08 & 0.14 & 0.22 \\
$0.20-0.30$ & 0.07 & 0.13 & 0.20 \\
\hline
\end{tabular}

Table 2. Chemical characteristics of the soil in the experimental site

\begin{tabular}{|c|c|c|c|c|c|c|c|c|c|c|}
\hline Depth & $\mathrm{pH}$ & $\mathrm{Ca}$ & $\mathrm{Mg}$ & $\mathrm{Na}$ & $\mathrm{K}$ & $\mathrm{H}+\mathrm{Al}$ & $\mathrm{Al}$ & BS & CEC & BS \\
\hline ------- m ------- & $\left(\mathrm{H}_{2} \mathrm{O}\right)$ & ---- & ---- & ---- & ---- & $\mathrm{c} / \mathrm{dm}^{-3}-$ & ----. & ------ & -------- & -- \% -- \\
\hline $0.0-0.10$ & 5.5 & 14 & 11 & 1.5 & 1.4 & 14.9 & 1.0 & 27.9 & 43 & 65 \\
\hline $0.10-0.20$ & 5.2 & 13 & 7.0 & 1.2 & 1.0 & 16.5 & 1.0 & 22.2 & 39 & 57 \\
\hline $0.20-0.30$ & 5.3 & 10 & 8.0 & 1.5 & 0.9 & 18.2 & 1.5 & 20.4 & 39 & 53 \\
\hline
\end{tabular}

Note. BS: Base saturation; CEC: Cation exchange capacity.

\subsection{Experimental Design}

The experimental design was of randomised blocks, in a $3 \times 2+1$ factorial scheme, with four replications.

\subsection{Treatments}

The treatments consisted of three forage species—Brachiaria Brizantha, Panicum maximum 'Mombasa', and Crotalaria spectabilis a.- intercropped with maize at two sowing times Phase 1: forage sown between rows of maize, mixed with the base dressing and Phase 2: forage sown between rows, at the V4 stage in maize. The treatments were: BE1-Brachiaria intercropped with maize, sown on the same day as maize; BE2-Brachiaria intercropped with maize, sown at V4 stage in maize; ME1-Mombasa intercropped with maize, sown on the same day as maize; ME2-Mombasa intercropped with maize, sown at V4 stage in the maize; CE1-Crotalaria 
intercropped with maize, sown on same day as the maize; CE2-Crotalaria intercropped with maize, sown at V4 stage in maize, in addition to control (C), maize with no intercrop.

\subsection{Experimental Plots}

The experimental plots consisted of three rows of maize spaced $0.80 \mathrm{~m}$ apart, and four rows of forage plants, two of which were between the central rows of maize and two at the sides. Each plot was $3 \mathrm{~m}$ in width and $15 \mathrm{~m}$ in length, with the central $5 \mathrm{~m}$ of the middle row of maize considered the working area.

\subsection{Planting Maize and Forage Crops}

Maize was sown mechanically using a Jumil model JM2090EX.00 precision pneumatic seeder-fertiliser, configured for three rows spaced $0.80 \mathrm{~m}$ apart. Seeds of the maize hybrid GNZ 2005 YG were used, aiming for a population of 70 thousand plants ha ${ }^{-1}$, at a sowing density of 6 seeds $\mathrm{m}^{-1}$.

The forages were sown manually at a spacing of $0.35 \mathrm{~m}$ between rows of maize. For the intercrops, $13 \mathrm{~kg} \mathrm{ha}^{-1}$ of Brachiaria brizantha, $12 \mathrm{~kg} \mathrm{ha}^{-1}$ of Mombasa and $11 \mathrm{~kg} \mathrm{ha}^{-1}$ of Crotalaria seeds were used, with a crop value of $50 \%$.

\subsection{Crop Treatments and Management}

Manual weed control was done when necessary. To control armyworm, the product Lufenurom (a.i) was applied thirteen days after sowing at a dose of $18 \mathrm{~g} \mathrm{ha}^{-1}$ active ingredient.

Irrigation was carried out by conventional spraying. I Irrigation time was calculated from the reference evapotranspiration estimated from evaporation measured in a class A tank, in $\mathrm{mm}$, and crop Kc values (Doorenbos \& Pruitt, 1977).

Basal dressing in maize used $250 \mathrm{~kg}$ fertiliser ha- ${ }^{-1}(10-28-20)$ in addition to cover fertiliser applied at $\mathrm{V}_{2}, \mathrm{~V}_{4}$ and $\mathrm{V}_{8}$ stages, using $300 \mathrm{~kg} \mathrm{ha}^{-1}$ urea and $120 \mathrm{~kg} \mathrm{ha}^{-1}$ potassium chloride.

\subsection{Harvesting and Evaluations}

Maize was harvested manually when grain moisture was around $18 \%$. The ears in the working area of each plot were harvested and the 1000-grain weight was evaluated, determined from the random count of eight replications of 100 grains, with their weight taken and adjusted to $13 \%$ wet basis for an estimate of the 1000 -grain weight.

To evaluate grain productivity, the ears collected were threshed in a semi-mechanical stationary thresher. The grains were separated and weighed, and the values corrected for $13 \%$ moisture based on the Rules for Seed Analysis MARA (1992), given by Equation 1:

$$
\mathrm{P}=\mathrm{I}[(100-\mathrm{U}) /(100-13)]
$$

where,

$\mathrm{P}=$ grain weight for $13 \%$ moisture $(\mathrm{kg})$; $\mathrm{U}=$ actual grain water content $(\%)$; $\mathrm{I}=$ initial weight of the sample $(\mathrm{kg})$.

For the determination of soil density, macro, micro and total porosity, samples were taken by introduction of metal rings in the soil, in the layers of $0.0-0.10 \mathrm{~m}, 0.10-0.20 \mathrm{~m}$, and $0.20-0.30 \mathrm{~m}$ depth, with a known volume (50 $\mathrm{mm}$ high and $43 \mathrm{~mm}$ in diameter). In the laboratory, the rings with samples were deposited for $48 \mathrm{~h}$ in a bowl with water aproximately $2 / 3$ of the ring height so that the samples were saturated. These were then weighed and conditioned in a tension table, where they were subjected to a maximum tension of $0.6 \mathrm{~m}$ of water column, to drain the water retained in the macropores (pores $>50 \mu \mathrm{m}$ ), being kept in this condition until reaching constant weight. When the mass values stabilized, the rings were again weighed and were brought to the oven at $105^{\circ} \mathrm{C}$ for $48 \mathrm{~h}$. After this step, the samples were weighed again. The ring mass was discounted at each step of obtaining the mass, as per Embrapa methodology (1997). The following formulas were applied to the data:

$$
\begin{aligned}
\text { Density }\left(\mathrm{kg} \mathrm{dm}^{-3}\right) & =\mathrm{SE} / \mathrm{V} \\
\text { Macroporosity }\left(\mathrm{m}^{3} \mathrm{~m}^{-3}\right) & =(\mathrm{SS}-\mathrm{SU}) / \mathrm{V} \\
\text { Microporosity }\left(\mathrm{m}^{3} \mathrm{~m}^{-3}\right) & =(\mathrm{SU}-\mathrm{SE}) / \mathrm{V} \\
\text { Total porosity }\left(\mathrm{m}^{3} \mathrm{~m}^{-3}\right) & =(\mathrm{Ma}+\mathrm{Mi})
\end{aligned}
$$

where,

$\mathrm{SS}$ is the mass of the saturated soil; $\mathrm{SU}$, the mass of the soil that received the $0.6 \mathrm{~m}$ column tension Water; SE, the mass of soil dried in an oven at $105{ }^{\circ} \mathrm{C}$; V, the internal volume of the ring; Ma, Macroporosity; Mi, Microporosity. 


\subsection{Statistical Analysis}

Statistical analysis was carried out with Assistat 7.6 beta software. The data were submitted to normality testing using the coefficient of symmetry and kurtosis. Analysis of variance (ANOVA) was then performed, and Dunnett's test used $(\mathrm{P}<0.05)$ to compare the mean values of the factors with the control.

\section{Results and Discussion}

With the values for macroporosity and microporosity in the $0.0-10 \mathrm{~m}$, and $0.10-0.20 \mathrm{~m}$ layers (Table 3), differences were seen for the forages within each sowing time when compared to control (monocropped maize). Mombasa forage sown in phase 1 (E1) and phase 2 (E2) gave higher values for macroporosity in the $0.0-0.10 \mathrm{~m}$ and 0.10-0.20 m layers respectively.

This result is possibly due to the a large root system of Mombasa forage with rapid initial growth. Pariz et al. (2009) state that Mombasa forage has a fairly vigorous growth habit and rapid establishment, which may have contributed to the higher values for soil macroporosity found in the said layers.

Salto et al. (2008) opined that grasses have abundant root systems, which may interfere directly in aggregate stability due to the action of the roots and the release of exudates by mycorrhizal hyphae. Stable aggregates provide good soil structure, promoting porous spaces for root development, soil fauna, and the circulation of water and air (Guedes Filho et al., 2013). Intercropping plants with different root systems results in an environment that is conducive to the formation and maintenance of soil aggregates, especially the macroaggregate class (Costa Jr. et al., 2012).

Table 3. Mean values for macroporosity and microporosity, evaluated in the $0.0-0.10,0.10-0.20$, and $0.20-0.30 \mathrm{~m}$ layers, for forage species and sowing time

\begin{tabular}{|c|c|c|c|c|}
\hline \multirow{2}{*}{ Cause of variation } & & \multicolumn{3}{|c|}{ Depth (m) } \\
\hline & & $0.0-0.10$ & $0.10-0.20$ & $0.20-0.30$ \\
\hline Forrage & Phase & \multicolumn{3}{|c|}{ Macroporosity $\left(\mathrm{m}^{3} \mathrm{~m}^{-3}\right)$} \\
\hline B. brizantha & E1 & $0.15 b$ & $0.09 \mathrm{~b}$ & 0.10 \\
\hline B. brizantha & E2 & $0.16 b$ & $0.15 \mathrm{a}$ & 0.12 \\
\hline Crotalaria & E1 & $0.12 b$ & $0.14 \mathrm{a}$ & 0.10 \\
\hline Crotalaria & E2 & $0.16 b$ & $0.16 \mathrm{a}$ & 0.16 \\
\hline Mombasa & E1 & $0.25 \mathrm{a}$ & $0.09 \mathrm{~b}$ & 0.13 \\
\hline Mombasa & E2 & $0.15 b$ & $0.17 \mathrm{a}$ & 0.11 \\
\hline $\mathrm{C}$ & & $0.15 \mathrm{~b}$ & $0.07 \mathrm{~b}$ & 0.12 \\
\hline $\mathrm{F} \times \mathrm{T}$ & & $1.18^{*-}$ & $86.69^{* *-}$ & $0.01^{\mathrm{NS}^{--}}$ \\
\hline LSD & & 0.04 & 0.03 & 0.09 \\
\hline $\mathrm{CV}(\%)$ & & 12.64 & 10.61 & 37.02 \\
\hline Forrage & Phase & \multicolumn{3}{|c|}{ Microporosity $\left(\mathrm{m}^{3} \mathrm{~m}^{-3}\right)$} \\
\hline B. brizantha & E1 & 0.07 & $0.14 \mathrm{a}$ & 0.14 \\
\hline B. brizantha & E2 & 0.08 & $0.07 \mathrm{~b}$ & 0.11 \\
\hline Crotalaria & E1 & 0.13 & $0.17 \mathrm{a}$ & 0.18 \\
\hline Crotalaria & E2 & 0.09 & $0.13 \mathrm{a}$ & 0.10 \\
\hline Mombasa & E1 & 0.10 & $0.14 \mathrm{a}$ & 0.14 \\
\hline Mombasa & E2 & 0.14 & $0.13 \mathrm{a}$ & 0.13 \\
\hline $\mathrm{C}$ & & 0.10 & $0.16 \mathrm{a}$ & 0.12 \\
\hline $\mathrm{F} \times \mathrm{T}$ & & $0.01 \mathrm{NS}^{-}$ & $10.23^{\text {*F- }}$ & $0.36^{\mathrm{NS}^{-}}$ \\
\hline LSD & & 0.08 & 0.04 & 0.06 \\
\hline $\mathrm{CV}(\%)$ & & 42.65 & 13.64 & 22.25 \\
\hline
\end{tabular}

Note. *: significant at a level of 0.05 probability $(\mathrm{p}<0.05)$ and $* *$ : significant at a level of 0.01 probability; ${ }^{\text {Ns }}$ : not significant. Mean values followed by the same letter and by no letter in a column do not differ by Dunnett's test $(\mathrm{p}<0.05)$. E1: Sowing time 1; E2: Sowing time 2; C: Control.

There were significant differences in the values for soil microporosity in the $0.10-0.20 \mathrm{~m}$ layer, where the Brachiaria brizantha forage, when inserted in phase 2 (E2), displayed lower values. The micropores are little altered by the handling because they are more resistant to deformation (Souza et al., 2008). In the 0.20-0.30 $\mathrm{m}$ 
layer, no significant effect from the forage was seen for the different sowing times, probably due to the root systems of the forages having found difficulty in developing in this layer due to higher mean values for bulk density (Table 4); this may have contributed to the lack of difference in the values for both macroporosity and microporosity in this layer.

With the values for total porosity (Table 4), evaluated in the 0.0-0.10, 0.10-0.20, and 0.20-0.30 m layers, the results were similar to those found for soil macro- and microporosity (Table 3), with significant differences and increases in the different forages for sowing time when compared to control. The results show that irrespective of sowing time, the Mombasa forage was superior to control (monocropped maize), as well as other forages.

From these results, it can be said that Mombasa forage has a very effective root system, capable of allowing root development at high soil densities, contributing to better gas exchange and water infiltration, and to a reduction in erosion. According to Cruciol et al. (2008), root growth in plants favours soil structuring that rebalances porosity and reduces density.

For bulk density, the maize intercropped with forages, irrespective of sowing time, had lower values when compared to the monocropped maize at depths of $0.10-0.20$, and $0.20-0.30 \mathrm{~m}$. These results possibly demonstrate that the forage species used, together with the two sowing times, cause significant effects to the point of improving that physical parameter of the soil.

Table 4. Mean values for total porosity and bulk density, evaluated in the $0.0-0.10,0.10-0.20$, and $0.20-0.30 \mathrm{~m}$ layers, for forage species and sowing time

\begin{tabular}{|c|c|c|c|c|}
\hline \multirow{2}{*}{ Cause of variation } & & \multicolumn{3}{|c|}{ Depth (m) } \\
\hline & & $0.0-0.10$ & $0.10-0.20$ & $0.20-0.30$ \\
\hline Forrage & Phase & \multicolumn{3}{|c|}{ Total porosity $\left(\mathrm{m}^{3} \mathrm{~m}^{-3}\right)$} \\
\hline B. brizantha & E1 & $0.23 b$ & $0.23 b$ & 0.26 \\
\hline B. brizantha & E2 & $0.24 b$ & $0.23 b$ & 0.22 \\
\hline Crotalaria & E1 & $0.25 b$ & $0.24 b$ & 0.28 \\
\hline Crotalaria & E2 & $0.25 b$ & $0.28 b$ & 0.27 \\
\hline Mombasa & E1 & $0.35 \mathrm{a}$ & $0.32 \mathrm{a}$ & 0.25 \\
\hline Mombasa & E2 & $0.29 \mathrm{a}$ & $0.30 \mathrm{a}$ & 0.24 \\
\hline $\mathrm{C}$ & & $0.25 \mathrm{~b}$ & $0.23 \mathrm{~b}$ & 0.25 \\
\hline $\mathrm{F} \times \mathrm{T}$ & & $8.74^{* *}$ & $4.90^{*}$ & $0.05 \mathrm{NS}$ \\
\hline LSD & & 0.04 & 0.05 & 0.08 \\
\hline $\mathrm{CV}(\%)$ & & 6.71 & 10.35 & 16.06 \\
\hline Forrage & Phase & \multicolumn{3}{|c|}{ Density $\left(\mathrm{kg} \mathrm{dm}^{-3}\right)$} \\
\hline B. brizantha & E1 & 1.66 & $1.75 b$ & $1.74 b$ \\
\hline B. brizantha & E2 & 1.71 & $1.68 \mathrm{~b}$ & $1.75 b$ \\
\hline Crotalaria & E1 & 1.66 & $1.73 b$ & $1.74 \mathrm{~b}$ \\
\hline Crotalaria & E2 & 1.65 & $1.74 \mathrm{~b}$ & $1.74 \mathrm{~b}$ \\
\hline Mombasa & E1 & 1.62 & $1.65 \mathrm{~b}$ & $1.70 \mathrm{~b}$ \\
\hline Mombasa & E2 & 1.69 & $1.71 \mathrm{~b}$ & $1.66 \mathrm{~b}$ \\
\hline $\mathrm{C}$ & & 1.69 & $1.80 \mathrm{a}$ & $1.82 \mathrm{a}$ \\
\hline $\mathrm{F} \times \mathrm{T}$ & & $0.35^{\mathrm{NS}}$ & $8.24^{*}$ & $4.50^{*^{-}}$ \\
\hline LSD & & 0.15 & 0.15 & 0.13 \\
\hline $\mathrm{CV}(\%)$ & & 4.48 & 4.29 & 3.86 \\
\hline
\end{tabular}

Note. *: significant at a level of 0.05 probability $(\mathrm{p}<0.05)$ and ${ }^{* *}$ : significant at a level of 0.01 probability; ${ }^{\mathrm{NS}}$ : not significant. Mean values followed by the same letter and by no letter in a column do not differ by Dunnett's test (p $<0.05)$. E1: Sowing time 1; E2: Sowing time 2; C: Control.

Considering the results found in the present study for the physical parameters of the soil, the hypothesis that an intercrop system of maize with forages contribute to the best physical soil conditions due to the high root density when compared with monocropped maize, is accepted and that forage of the genus Panicum results in improving the physical conditioning of the soil. 
Table 5 shows the results of the treatments under intercropping compared to control for 1000-grain weight and grain productivity, where it can be seen that there were no significant differences between treatments when compared to the monocropped maize, showing that intercropping did not influence the production variables.

Pereira et al. (2014) evaluating the technical performance of maize intercropped with two forage species of the genus Panicum and Brachiaria, did not find significant differences for the different forage species and sowing modality.

Seidell et al. (2014), evaluating the effect of sowing time and the system of forages intercropped with maizealso found no difference in maize productivity. On the other hand, Ferreira et al. (2014) evaluating the performance and efficiency of land use of different types of intercropping with maize and forage crops found that grain yield of maize was higher in monoculture compared to that obtained in intercropping systems. Mendes et al. (2015) concluded that the productivity of maize grain is higher as a monocrop, when compared to intercropping systems.

For Pereira et al. (2011), intercropping favours the accumulation of organic matter and nutrients in the soil by means of processes of mineralisation and decomposition, allowing these systems to present significant results with the passage of time, and explaining the lack of difference found in the present study.

Despite the lack of difference between treatments for the production variables, it can be seen that productivity in the maize was not altered by intercropping with forages at different sowing times. It should however be noted that the results for productivity found in this study are higher than the national average (CONAB, 2016).

Table 5. Mean values for 1000-grain weight and maize production under a forage-maize intercrop system for different sowing times

\begin{tabular}{llll}
\hline Forrage & Phase & 1000 -Grain weight $(\mathrm{kg})$ & Productivity $\left(\mathrm{kg} \mathrm{h}^{-1}\right)$ \\
\hline B. brizantha & E1 & 0.399 & 6.475 \\
B. brizantha & E2 & 0.393 & 6.286 \\
Crotalaria & E1 & 0.400 & 6.925 \\
Crotalaria & E2 & 0.397 & 6.709 \\
Mombasa & E1 & 0.401 & 6.595 \\
Mombasa & E2 & 0.402 & 7.862 \\
\hline C & M & 0.410 & 6.942 \\
\hdashline F $\times$ T & & $0.99^{\mathrm{NS}}$ & $0.015^{\mathrm{NS}^{-1}}$ \\
LSD & 0.043 & 3.982 \\
\hline CV (\%) & 5.37 & 29.14
\end{tabular}

Note. Mean values followed by the same letter and by no letter in a column do not differ by Dunnett's test $(\mathrm{p}<$ 0.05), E1: Sowing time 1; E2: Sowing time 2; C: Control.

\section{Conclusions}

Intercropping maize with forages results in changes to the physical properties of the soil, with increases in macroporosity and total porosity, in the $0.0-0.10$ and $0.10-0.20$ m layers.

Mombasa forage, irrespective of sowing season, promotes greater changes in macroporosity and total porosity.

Productivity in maize crop is not affected, independently of forage in a consortium or sowing time. Intercropping systems that link forages with grain crops are therefore an excellent alternative to monocrop systems, since they support environmental sustainability, as well as the diversification of products and activities in any one area.

\section{Acknowledgements}

We recognize the institutions of the Coordination of Improvement of Higher Education Personnel (CAPES), Brazil, for the financial support.

\section{References}

Carvalho, A. M., Coser, T. R., Rein, T. A., Dantas, R. A., Silva, R. R., \& Souza, K. W. (2015). Manejo de plantas de cobertura na floração e na maturação fisiológica e seu efeito na produtividade do milho. Pesquisa Agropecuária Brasileira, 50(7), 551-561. https://doi.org/10.1590/S0100-204X2015000700005 
CONAB (Companhia Nacional de Abastecimento). (2016). Acompanhamento Safra Brasileira Grãos, Brasília (pp. 1-100).

Coser, T. R. C., Ramos, M. L. G., Figueiredo, C. C., Carvalho, A. M., Cavalcante, E., Moreira, M. K. R., ... Oliveira, S. A. (2016). Soil microbiological properties and available nitrogen for corn in monoculture and intercropped with forage. Pesquisa Agropecuária Brasileira, 51(9), 1660-1667. https://doi.org/10.1590/ s0100-204x2016000900066

Costa Jr., C., Piccolo, M. C., Siqueira Neto, M., \& Bernoux, M. (2012). Carbono em agregados do solo sob vegetação nativa, pastagem e sistemas agrícolas no bioma Cerrado. Revista Brasileira Ciência do Solo, 33(1), 1-12. https://doi.org/10.1590/S0100-06832012000400025

Crusciol, C. A. C., \& Borghi, E. (2008). Consórcio de milho com braquiária: Produção de forragem e palhada para o plantio direto. Revista Plantio Direto, 100(3), 177-183.

EMBRAPA (Empresa Brasileira de Pesquisa Agropecuária). (1997). Manual de métodos de análises de solo (p. 212). Embrapa, Rio de Janeiro, Brasil.

EMBRAPA (Empresa Brasileira de Pesquisa Agropecuária). (2013). Sistema Brasileiro de Classificação de Solos (p. 353). Embrapa, Brasília, Brasil.

Ferreira, E. A., Coletti, A. J., Silva, W. M., Macedo, F. G., \& Albuquerque, A. N. (2014). Desempenho e uso eficiente da terra de modalidades de consorciação com milho e forrageiras. Revista Caatinga, 27(3), 22-29.

Ferreira, J. P., Andreotti, M., Pascoaloto, I. M., Costa, N. R., \& Augusto, J. G. (2017). Componentes de produção e produtividade do milho consorciado com forrageiras sob diferentes espaçamentos em plantio direto no cerrado. Revista Tecnologia \& Ciência Agropecuária, 11(5), 9-14.

Garcia, C. M. P., Andreotti, M., Teixeira Filho, M. C. M., Buzetti, S., Celestrino, T. S., \& Lopes, K. S. M. (2013). Desempenho Agronômico da cultura do milho e espécies forrageiras em sistemas de integração lavoura pecuária no cerrado. Ciência Rural, 43(4), 589-595. https://doi.org/10.1590/S0103-84782013000400005

Guedes Filho O., Silva, A. P., Giarola, N. F. B., \& Tormena, C. A. (2013). Structural properties of the soil seedbed submitted to mechanical and biological chiseling under no-tillage. Geoderma, 204(205), 94-101. https://doi.org/10.1016/j.geoderma.2013.04.017

Magalhães, I. D., Soares, C. S., Costa, F. E., Almeida, A. E. S., Oliveira, A. B., \& Vale, L. S. (2013). Viabilidade do consórcio mamona-gergelim para a agricultura familiar no semiárido paraibano: Influência de diferentes épocas de plantio. Revista Brasileira de Agroecologia, 8(1), 57- 65.

MARA (Ministério da Agricultura e Reforma Agrária). (1992). Regras para análise de sementes (p. 365). Brasília: SNDA/DNPV/CLAV.

Mendes, W. C., Ximenes, P. A., Paulo Cunha, P. C. R., Júnior, J. A., Costa, R. B., Cunha, P. P., \& Marangon, R. E. (2015). Produtividade de fitomassa e desempenho agronômico do milho em cultivo solteiro e consorciado com Urochloa ruziziensis. Revista Global Science and Technology, 8(1), 87-95. https://doi.org/10.14688/ 1984-3801/gst.v8n1p87-95

Mendonça, V. Z., Mello, L. M. M., Andreotti, M., Pereira, F. C. B. L., Lima, R. C., Filho, W. V. V., \& Yano. (2013). Avaliação dos atributos físicos do solo em consórcio de forrageiras e milho em sucessão com soja em região de cerrados. Revista Brasileira Ciência do Solo, 37(1), 251-259. https://doi.org/10.1590/ S0100-06832013000100026

Neto, F. A., Petter, F. A., Pavan, B. E., Schmitt, C. R., Almeida, F. A., Pacheco, L. P., \& Piauilino, A. C. (2012). Desempenho agronômico de cultivares de soja em duas épocas de semeadura no cerrado piauiense. Revista Comunicata Scientiae, 3, 215-219.

Pariz, C. M., Andreotti, M., Tarsitano, M. A. A., Bergamaschine, A. F., Buzetti, S., \& Chioderoli, C. A. (2009). Desempenhos técnicos e econômicos da consorciação de milho com forrageiras dos gêneros panicum e brachiaria em sistema de integração lavoura-pecuária. Revista Pesquisa Agropecuária Tropical, 39(4), 360-370.

Pereira, F. C. B. L., Mendonça, V. Z., Leal, S. T., \& Rossetto. J. É. (2014). Avaliação econômica e do desempenho técnico do milho consorciado com duas espécies forrageiras dos gêneros panicum e brachearia em sistema de integração lavoura-pecuária. Revista Agrarian, 7(23), 157-165. 
Pereira, L. C., Fontaneti, A., Batista, N. J., Galvão, J. C. C., \& Goulart, P. L. (2011). Comportamento de cultivares de milho consorciados com Crotalaria juncea: estudo preliminar. Revista Brasileira de Agroecologia, 6(3), 191-200.

Salton, J. C., Mielniczuk, J., Bayer, C., Boeni, M., Conceicao, P. C., Fabrício, A. C., Macedo, M. C. M., \& Broch, D. L. (2008). Agregação e estabilidade de agregados do solo em sistemas agropecuários em Mato Grosso do Sul. Revista Brasileira de Ciência do Solo, 32(1), 11-21. https://doi.org/10.1590/S0100-0683200800010 0002

Seidel, P. E., Gerhardt, S. F. I., Castagnara, D., \& Neres, A. D. M. (2014). Efeito da época e sistema de semeadura da Brachiaria brizantha em consórcio com o milho, sobre os componentes de produção e propriedades físicas do solo. Revista Ciências Agrárias, 35(1), 55-66. https://doi.org/10.5433/1679-0359. $2014 \mathrm{v} 35 \mathrm{n} 1 \mathrm{p} 55$

Simão. (2016). Características agronômicas e nutrição do milho safrinha em função de épocas de semeadura e adubação (p. 70, Dissertação (Mestrado), Universidade Federal de São João Del-Rei, Minas Gerais).

Souza, N. E. L., Andrioli, I., Beutler, A. N., \& Centurion, J. F. (2008). Atributos físicos do solo e produtividade de milho em resposta a culturas de pré-safra. Revista Pesquisa Agropecuária Brasileira, 43(2), $255-260$. https://doi.org/10.1590/S0100-204X2008000200015

\section{Copyrights}

Copyright for this article is retained by the author(s), with first publication rights granted to the journal.

This is an open-access article distributed under the terms and conditions of the Creative Commons Attribution license (http://creativecommons.org/licenses/by/4.0/). 